Vol.1 No.1 Januari 2018

ISSN 2614-2775

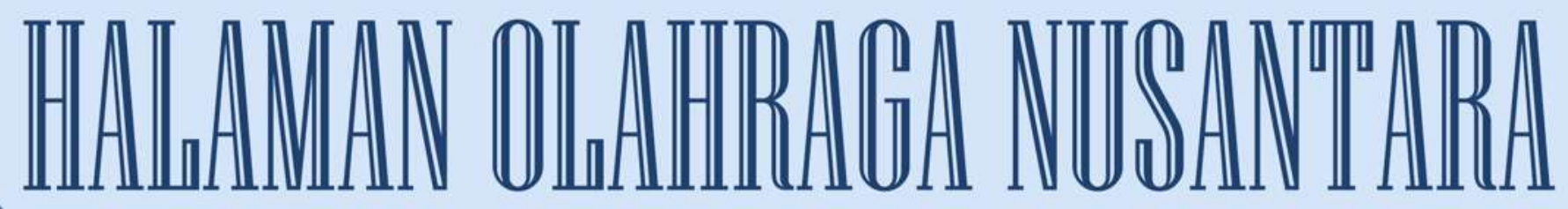

Curnal \&lmu Q Xeolahragaan

Diterbitkan Oleh:

Program Studi Pendidikan Olahraga

Pakultas Keguruan dan Ilmu Pendidikan

Universitas PGRI Palembang

\begin{tabular}{|c|c|c|c|c|c|}
\hline Jurnal & Volume & Nomor & Halaman & Palembang & ISSN \\
\hline IItaman Oahraya Vissantara & 1 & 1 & $1 \cdot 132$ & 2018 & 2014.27175 \\
\hline
\end{tabular}


Artikel Ilmiah

Perbedaan Variasi Latihan Juggling dan Rasio Koordinasi Mata-Kaki terhadap Hasil Kontrol Bola dari Tendangan Jarak Jauh Sepak Bola Hengki Kumbara

Hubungan Antara Kekuatan Otot Tungkai dan Kekuatan Otot Lengan terhadap Hasil Kecepatan Renang 50 Meter Gaya Bebas pada Atlet Putri Club Bangka Swimming

Farizal Imansyah

Motivasi Mahasiswa PGSD dalam Olahraga Rekreasi di Water Fun Kota Palembang

M. TaheriAkikbar

Pengaruh Metode Sirkuit terhadap Kemampuan Teknik Dasar Sepakbola pada Kegiatan Ekstrakurikuler Siswa SMAN 5 Kabupaten Tebo Alek Oktadinata

Kontribusi. Daya Ledak Otot Thung:kai dan Kelentukan dengan [1asil] Lompat Tinggi Gaya Flop Mahasiswa Program Studi Pendidikan Olahraga Universitas PG:RIPalembang IIham Arvan Junaidi

Kemampuan Meng.gining Bola (IStudi Korelasional Kecepatan ( $\left.x_{1}\right)$ dan Kelineahan $\left(x_{2}\right)$ dengan Kemampuan Dribel pada Permainan Sepabola Siswa Sekolah Menengah Pertama) Putwi Cicilla Kristina

Revitalisasi Masyarakat ¿iban/Perkotaan Melalui Olahraga Petanque Arcdo okilanda

Peranan Mata Pelajaran Pendidikan Jasmani dalam Meningkatkan Kesadaran Kesehatan \$iswa đi Lingkungan \$ekolah Dasar

Negeri nur Tegalkalong Kabupaten sumedang

№ Siti nurfaeni Sofa dan Anggi Setia Lengkana

Peran Motor Educability di dalam Meningkatan Keterampilan Olahraga pada Pembelajaran Penjas

gieru Syarili Lesmana

MơtivasiAnggota Pusat Kebugaran dalam Mengikuti Latihan Fitness padaKota Sekaycu Sugar Wanto

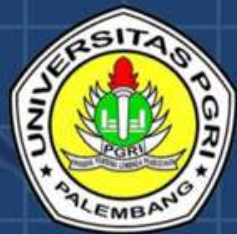

Program Studi Pendidikan Olahraga Fakultas Keguruan dan Ilmu Pendidikan Universitas PGRI Palembang 
ISSN 2614-2775

\section{HALAMAN OLAHRAGA NUSANTARA}

Jurnal Ilmu Keolahragaan

Volume 1, Nomor 1, Januari 2018

Pelindung/Penasehat

Dr. H. Bukman Lian, M. M., M. Si.

Penanggung Jawab

Dr. Dessy Wardiah, M. Pd.

Ketua Dewan Redaksi

Drs. M. Nirwan, M. Pd.

\section{Wakil Ketua Dewan Redaksi}

Ilham Arvan Junaidi, M. Pd.

\section{Sekretaris}

Nasrullah, M. Pd.

Penyunting Pelaksana

Rafel Orlando, M. Pd

Ardo Okilanda, M. Pd

\section{Penyunting Ahli/ Mitra Bestari}

Prof. Dr. A. Sofyan Hanif, M. Pd (Universitas Negeri Jakarta)

Dr. Ronni Yenes, M. Pd (Universitas Negeri Padang)

Dr. Putri Cicilia Kristina, M. Pd (Universitas PGRI Palembang)

\section{Tata Usaha}

M. Taheri Akbar, M. Pd

\section{Setting:}

Dede Dwiansyah Putra, M. Pd

Alamat Redaksi:

Prodi Pendidkan Olahraga Fakultas Keguruan Ilmu dan Pendidikan Universitas PGRI Palembang

Jl. Jendral A. Yani Lorong Gotong Royong 9/10 Ulu Palembang Telp. 0711-510043, Fax. 0711-514782

e-mail jurnal: rafelorlando333@gmail.com

e-mail : ardo.oku@ univpgri-palembang.ac.id

website: univpgri-palembang.ac.id 


\section{DAFTAR ISI}

Perbedaan Variasi Latihan Juggling dan Rasio Koordinasi Mata-Kaki terhadap Hasil Kontrol Bola dari Tendangan Jarak Jauh Sepak Bola

Hubungan Antara Kekuatan Otot Tungkai dan Kekuatan Otot Lengan terhadap Hasil Kecepatan Renang 50 Meter Gaya Bebas pada Atlet Putri Club Bangka Swimming

- Farizal Imansyah

Motivasi Mahasiswa PGSD dalam Olahraga Rekreasi di Water Fun Kota Palembang

- $\quad$ M. Taheri Akhbar

Pengaruh Metode Sirkuit terhadap Kemampuan Teknik Dasar Sepakbola pada Kegiatan Ekstrakurikuler Siswa SMAN 5 Kabupaten Tebo

- Alek Oktadinata

Kontribusi Daya Ledak Otot Tungkai dan Kelentukan dengan Hasil Lompat Tinggi Gaya Flop Mahasiswa Program Studi Pendidikan Olahraga Universitas PGRI Palembang

- Ilham Arvan Junaidi

Kemampuan Menggiring Bola (Studi Korelasional Kecepatan $\left(\mathrm{x}_{1}\right)$ dan Kelincahan $\left(\mathrm{x}_{2}\right)$ dengan Kemampuan Dribel pada Permainan Sepabola Siswa Sekolah Menengah Pertama)

- Putri Cicilia Kristina

Revitalisasi Masyarakat Urban/Perkotaan Melalui Olahraga Petanque

- $\quad$ Ardo okilanda

Peranan Mata Pelajaran Pendidikan Jasmani dalam Meningkatkan

Kesadaran Kesehatan Siswa di Lingkungan Sekolah Dasar

Negeri III Tegalkalong Kabupaten Sumedang

- $\quad$ N. Siti nur'aeni Sofa dan Anggi Setia Lengkana

Peran Motor Educability di dalam Meningkatan Keterampilan

Olahraga pada Pembelajaran Penjas

- Heru Syarli Lesmana 
Motivasi Anggota Pusat Kebugaran dalam Mengikuti Latihan Fitness pada Kota Sekayu

Sugar Wanto 


\title{
MOTIVASI ANGGOTA PUSAT KEBUGARAN DALAM MENGIKUTI LATIHAN FITNESS PADA KOTA SEKAYU
}

\author{
Oleh: Sugar Wanto \\ (Dosen Universitas PGRI Palembang)
}

\begin{abstract}
Abstrak
Pusat kebugaran menjadi salah satu tempat yang menyediakan dan menjalankan program-program latihan kebugaran jasmani, yang tidak saja memberikan manfaat secara langsung seperti peningkatan derajat kebugaran dan kesehatan jasmani, tetapi juga memberikan keleluasaan untuk mengekspresikan segala kebutuhan seperti sosialisasi, aktualisasi, pemanfaatan waktu luang, bisnis dan sebagainya. Tujuan penelitian adalah untuk mengetahui motivasi anggota pusat kebugaran dalam mengikuti latihan fitness di Kota Sekayu. Metode penelitian yang digunakan dalam penelitian ini adalah metode survey. Sampel penelitian berjumlah 26 orang. Teknik pengumpulan data dilaksanakan dengan observasi, kuisioner/ angket dan dokumentasi. Teknik analisis data penelitian menggunakan deskripsi persentase. Penelitian ini memberikan kesimpulan motivasi member dalam mengikuti latihan fitness di Kota Sekayu termotivasi karena faktor internal adalah sebesar 23,5\% dan termotivasi karena faktor eksternal adalah sebesar 18,65\%.
\end{abstract}

Kata Kunci: Pusat Kebugaran, Motivasi Anggota Pusat Kebugaran, Fitness

\section{MOTIVATION OF FITNESS CENTER MEMBERS IN FOLLOWING FITNESS EXERCISE AT THE SEKAYU CITY}

\begin{abstract}
The fitness center is one of the places that provides and runs physical fitness training programs, which not only provide immediate benefits such as fitness and physical fitness improvement, but also provide the freedom to express all needs such as socialization, actualization, leisure time usage, business etc. The purpose of this research is to know the motivation of fitness center member to follow fitness training in Sekayu City. The research method used in this research is survey method. The sample of research is 26 people. Data collection techniques were carried out by observation, questionnaire / questionnaire and documentation. Technique of data analysis of research use description percentage. This study gives the conclusion of member motivation in following fitness training in Sekayu city motivated because internal factor is 23,5\% and motivated because external factor is equal to 18,65\%.
\end{abstract}

Keywords: Fitness Centre, Member's Motivation Fitness, Fitness 


\section{A. PENDAhuluan}

WHO (World Health Organization) mendefinisikan sehat adalah dimana kondisi tubuh dalam keadaan sehat jasmani dan rohani atau sehat fisik dan mental. Dikatakan sehat fisik dan mental adalah terhindarnya penyakit yang berkaitan dengan penyakit fisik dan mental yang mendera tubuh manusia. Sedangkan kebugaran adalah kemampuan kerja fisik dalam melakukan aktivitas sehari-hari tanpa mengalami kelelahan yang berarti. Perkembangan zaman yang semakin meningkat, di imbangi dengan banyaknya virus, bakteri dan jamur yang semakin mudah terkontaminasi dengan tubuh manusia membuat semua orang wajib menjaga kesehatan dan kebugaran tubuh. Salah satu cara sederhana yang telah dilakukan banyak orang untuk menjaga kebugaran tubuh adalah dengan cara berolahraga.

Olahraga mengandung arti akan adanya sesuatu peristiwa yang berhubungan dengan mengolah raga atau mengolah jasmani. Olahraga mempunyai arti yang seluas-luasnya yang meliputi segala kegiatan dan usaha untuk mendorong, membimbing, membangkitkan dan mengembangkan jasmani maupun rohani. Definisi olahraga menurut UU nomor 3 Tahun 2005 pada BAB I, Pasal 1 poin 4-6 yang berbunyi:

"Olahraga adalah segala kegiatan yang sistematis untuk mendorong, membina, serta mengembangkan potensi jasmani, rohani, dan sosial. Pelaku olahraga adalah setiap orang dan/atau kelompok orang yang terlibat secara langsung dalam kegiatan olahraga yang meliputi pengolahraga, pembina olahraga, dan tenaga keolahragaan. Olahragawan adalah orang yang berolahraga dalam mengembangkan potensi jasmani, rohani, dan sosial."

Ada banyak hal yang mendorong atau memotivasi seseorang untuk berolahraga, diantaranya adalah, waktu luang, life syle (gaya hidup), espektasi kesehatan dan olahraga prestasi. Motivasi berarti dorongan atau kemauan yang timbul pada diri seseorang maupun kelompok terhadap suatu tujuan yang diinginkan. Motivasi merupakan dorongan internal atau timbul dari dalam diri 
manusia itu sendiri. Menurut Kamus Besar Bahasa Indonesia, survei adalah teknik riset yang bertugas untuk mengadakan pemerikasaan penyelidikan dan peninjauan pada keadaan tertentu. Berkaitan dengan survey di atas, yang akan di selidiki dan di tinjau adalah mengenai motivasi anggota pusat kebugaran. Sukirno (2011: 48) berpendapat bahwa motivasi berasal dari kata motif yang dapat diartikan sebagai tenaga penggerak yang dapat mempengaruhi untuk memulai dan melakukan serangkaian kegiatan dalam suatu perilaku seseorang. Sedangkan menurut Sabran (2005: 7), motivasi adalah dorongan di dalam yang berupa harapan dan keinginan yang bersifat menggiatkan dan menggerakan individu.

Dan berkaitan dengan kebugaran, dewasa ini banyak sekali tempat-tempat kebugaran yang bermunculan mulai dari kota-kota besar, sampai kepada kotakota kecil. Pusat kebugaran menjadi salah satu tempat yang menyediakan dan menjalankan program-program latihan kebugaran jasmani, yang tidak saja memberikan manfaat secara langsung seperti peningkatan derajat kebugaran dan kesehatan jasmani, tetapi juga memberikan keleluasaan untuk mengekspresikan segala kebutuhan seperti sosialisasi, aktualisasi, pemanfaatan waktu luang, bisnis dan sebagainya. Orang-orang mengenal tempat pusat kebugaran dengan istilah fitness center. Suryono (2004: 34) berpendapat bahwa fitness center, atau dalam bahasa Indonesianya pusat kebugaran biasa lebih dikenal dengan istilah "gym" adalah suatu tempat untuk menampung berbagai macam alat-alat latihan kesehatan untuk mengadakan kegiatan latihan fisik. Sedangkan Utomo (2008: 17) menyatakan bahwa fitness center merupakan suatu layanan dibidang kesehatan yang membantu masyarakat umum meningkatkan kesehatan fisik, dimana tidak hanya masyarakat menjadi lebih sehat, tapi juga lebih termotivasi, memiliki kepercayaan diri dan semangat hidup.

Banyak orang memanfaatkan fitness center sebagai media untuk memperoleh kebugaran. Selain itu tak jarang beberapa orang juga melatih fisiknya pada fitness center untuk berprestasi dibidang olahraga, misalnya 
menjadi seorang binaragawan, seorang lifter atau atlet angkat berat dan angkat besi, atau ada juga yang memanfaatkan fitness center sebagai tempat untuk melatih kemampuan biomotor yang dibutuhkan oleh atlet untuk cabangolaharaga tertentu. Contohnya melatih kekuatan otot lengan untuk para atlet bela diri, kekuatan otot tungkai untuk atlet permainan dan lain sebagainya.

\section{Motivasi}

Hamzah (2008: 1) menyatakan bahwa "motivasi adalah dorongan dasar yang menggerakan seseorang bertingkah laku”. Sedangkan Husdarta (2010: 31) menyatakan bahwa motivasi adalah energi psiokologi yang bersifat absrtak atau refleksi kekuatan interaksi antara kongnisi, pengalaman dan kebutuhan. Irianto mengatakan (2005: 53) bahwa motivasi sesuatu yang menggerakkan atau mendorong seseorang atau kelompok untuk melakukan atau tidak melakukan sesuatu. Mylsidayu (2014: 32) berpendapat bahwa motivasi adalah kekuatan yang mendorong seseorang untuk bereaksi atau tidak bereaksi untuk menentukan arah atau aktivitas terhadap tujuan pencapaian, motivasi sangat penting dalam proses belajar, penampilan olahraga dan pencapaian prestasi. Sukirno (2011: 48) menyatakan bahwa:

"Motivasi berasal dari kata motif yang dapat diartikan sebagai tenaga penggerak yang dapat mempengaruhi untuk memulai dan melakukan serangkaian kegiatan dalam suatu perilaku seseorang. Dorongan ini berada pada diri seseorang yang menggerakkan untuk melakukan sesuatu yang sesuai dengan dorongan dalam dirinya. Oleh karena itu, perbuatan seseorang yang didasarkan atas motivasi tertentu mengandung tema sesuai dengan motivasi yang mendasarinya."

Dari beberapa pendapat di atas dapat disimpulkan mengenai teori motivasi adalah dorongan atau kemauan yang timbul pada diri seseorang maupun kelompok terhadap suatu tujuan yang diinginkan. Motivasi merupakan dorongan internal atau timbul dari dalam diri manusia itu sendiri. 


\section{Pusat Kebugaran (Fitness Center)}

Suryono (2004: 34) menyatakan bahwa fitness center atau dalam bahasa Indonesianya pusat kebugaran biasa lebih dikenal dengan istilah "gym" adalah suatu tempat untuk menampung berbagai macam alat-alat latihan kesehatan untuk mengadakan kegiatan latihan fisik. Sedangkan Utomo (2008: 17) menyatakan bahwa fitness center merupakan suatu layanan dibidang kesehatan yang membantu masyarakat umum meningkatkan kesehatan fisik, dimana tidak hanya masyarakat menjadi lebih sehat, tapi juga lebih termotivasi, memiliki kepercayaan diri dan semangat. Sekarang ini sebuah fitness center juga memiliki fasilitas ruang untuk melakukan kegiatan bersama seperti ruang aerobik, untuk yoga, dan kegiatan semacamnya. Apabila sebuah fitness center memiliki modal yang cukup maka dapat juga menyediakan fasilitas untuk Olahraga, seperti lapangan tenis, kolam renang, boxing. Biasanya untuk menggunakan fasilitas ini tentu saja pelanggan akan dikenai biaya tambahan. Fasilitas tambahan lainnya bisa berupa restoran, café, spa, sauna dan mandi uap.

Ismaryati (2009: 39) menyatakan bahwa kebugaran jasmani lebih dititik beratkan kepada physiological fitness, yaitu kemampuan tubuh untuk menyesuaikan fungsi alat-alat tubuhnya dalam batas-batas fisiologis terhadap keadaan lingkungan dan kerja fisik dengan cara yang cukup efisien tanpa lelah secara berlebihan. Sedangkan Purwanto (2006: 94) dalam jurnal olahraga mengatakan bahwa tingkat kebugaran jasmani seseorang terkait erat dengan tingkat kesehatan jasmani yang disandangnya. Artinya, seseorang yang memiliki tingkat kebugaran jasmani baik tentunya juga memiliki tingkat kesehatan jasmani yang baik pula.. Kemudian purwanto (2006: 97) berpendapat:

"Istilah Physical fitness atau Kebugaran jasmani merupakan salah satu aspek fisik dari kebugaran secara menyeluruh (total fitness). Pengertian kebugaran jasmani adalah kesanggupan seseorang menjalankan hidup secara produktif dan dapat menyesuaikan diri pada 
setiap pembebanan fisik yang layak,oleh karena itu, berat ringannya tugas fisik pada diri seseorang sifatnya individual dan tergantung pada tugas pekerjaan yang dihadapi oleh setiap orang. Sebagai contoh berat ringannya tugas fisik seorang pegawai administrasi padakantor pemerintah tentu akan berbeda dengan tugas fisik seorang tukang kebun (pesuruh)."

Kebugaran jasmani diartikan sebagai tingkat kesehatan yang sesuai dengan tubuh untuk melakukan pekerjaan tertentu. Berdasarkan pengertian tersebut, di dalam kebugaran jasmani terdapat tiga unsur yang saling berpengaruh, yaitu: (1) sehat, (2) sesuai dengan kemampuan tubuh, dan (3) kerja yang dilakukan. Sehat secara fisiologis adalah normalnya fungsi peralatan tubuh. Kesesuaian dengan kemampuan tubuh adalah kemampuan tubuh dalam menyesuaikan atau mengadaptasi dengan kerja, sehingga tidak cepat lelah dan dapat aktif melaksanakan tugas yang harus diembannya. Kerja pada dasamya merupakan peningkatan proses faal dan biokimia sebagai

jawaban terhadap meningkatnya tuntutan organ-organ tubuh maupun sistem seluruh tubuh.

\section{B. METODOLOGI PENELITIAN}

Metode penelitian yang digunakan dalam penelitian ini adalah metode survey. Sampel penelitian berjumlah 26 orang. Teknik pengumpulan data dilaksanakan dengan observasi, kuisioner/angket dan dokumentasi. Teknik analisis data penelitian menggunakan deskripsi persentase.

\section{SIMPULAN DAN SARAN}

Penelitian ini memberikan kesimpulan bahwa motivasi member dalam mengikuti latihan fitness di kota sekayu disebabkan karena faktor internal sebanyak 23,5\% dan termotivasi karena faktor eksternal sebanyak 18,65\%. Sesuai dengan hasil penelitian dan kesimpulan yang didapat dari penelitian 
ini, maka peneliti mencoba memberi babarapa saran yang dapat dikemukakan untuk studi lebih lanjut antara lain sebagai berikut.

a. Kepada pihak tempat kebugaran jasmani untuk melengkapi sarana dan prasarana penunjang aktivitas gym agar member lebih termotivasi.

b. Kepada para peneliti lain diharapkan dapat mengembangkan penelitian ini dengan jumlah sampel yang lebih banyak lagi atau dengan variabelvariabel lain yang belum diteliti sehingga factor-faktor yang mempengaruhi tingkat kesegaran jasmani masyarakat pencintas olahraga gym dapat diketahui.

c. Bagi pelatih gym dan insan olahraga agar penelitian ini dapat dijadikan referensi sebagai bahan pengembangan penelitian

\section{DAFTAR PUSTAKA}

Hamzah. 2008. Psikologi Pendidikan. Yogyakarta: Multimedia Cipta.

Husdarta, H.J.S. 2010. Psikologi Olahraga. Bandung: Alfabeta. 2010. Sejarah dan Falsafah Olahraga. Bandung: Alfabeta.

Ismaryati, 2009. Tes dan Pengukuran Olahraga. Surakarta: UNS Press.

Mylsidayu, Apta. 2004. Psikologi Olahraga. Bandung: Bumi Aksara.

Poerwanto. 2006. Olahraga. Yogyakarta: FIK.

Sabran. 2005. Motif dan Motivasi. Bandung: Galileo.

Suryono. 2004. Pusat Kebugaran. Unesa: FIK.

Sukirno. 2011. Psikologi Olahraga. Palembang: Universitas Sriwijaya

Utomo, Budi. 2008. Physical Fitness. UPI: Bandung.

UU Nomor 3 Tahun 2005. Sistem Keolahragaan Nasional. Kementerian Pemuda dan Olahraga. 